\title{
Price Discount: Pengaruhnya terhadap Online Customer Review dan Purchase Intention pada Konsumen Online Marketplace Platform pada Masa Pandemi Covid-19
}

\author{
Dyajeng Puteri Woro Subagio*, Sri Hastari \\ Program Studi Manajemen Fakultas Ekonomi, Universitas Merdeka Pasuruan, \\ Pasuruan, Indonesia \\ *dyajengsubagio@gmail.com
}

\begin{abstract}
The COVID-19 pandemic significant impact on decreasing income and community activities, including shopping behavior. Many people have decided to use the online marketplace platform to shop for various needs. This study aims to investigate the direct and indirect relationships among variable price discounts, Online Customer Reviews (OCR), and purchase intentions for consumers of the 5 most popular online marketplace platforms in Indonesia during the COVID-19 pandemic. Collecting data in this study using an online questionnaire to 120 respondents as a sample who have met the purposive sampling criteria. This study uses Partial Least Square (PLS) to analyze the data. There is a uniqueness in this study where the price discount strategy is not able to directly influence consumer purchase intention even though the economic condition has decreased due to the pandemic. This strategy encourages consumers to seek information through online customer reviews. Information on OCR affects consumer purchase intention in a product. This makes OCR able to fully mediate the relationship between the price discount strategy and purchase intention.
\end{abstract}

Keywords: COVID-19 Pandemic, Online Customer Review, Online Marketplace Platform, Price Discount, Purchase Intention

\section{PENDAHULUAN}

Pandemi COVID-19 atau coronavirus disease 2019 pertama kali terdeteksi di Kota Wuhan, Provinsi Hubei, Cina, pada Desember 2019. Umumnya, COVID-19 merupakan penyakit yang dapat disembuhkan tetapi juga bisa mematikan, dengan kasus $5,3 \%$ tingkat kematian (WHO, 2020). Seseorang dengan imunitas yang lemah memiliki risiko yang tinggi jika terpapar virus tersebut, oleh karenanya perlu adanya penanganan secara medis dan pengisolasian. COVID-19 sangat mudah tersebar dan menular melalui tetesan kecil (droplet) yang dikeluarkan pada saat penderita positif melalui batuk atau bersin (WHO, 2020).

Bahaya yang disebabkan oleh pandemi COVID-19 membuat semua negara di dunia termasuk Indonesia yang telah mengumumkan kasus pertamanya pada tanggal 11 Maret 2020 dan angka penyebarannya terus meningkat mengambil langkah pencegahan berupa physical distancing atau pembatasan fisik. Kebijakan tersebut diambil oleh berbagai negara sebagai cara untuk meminilisir penyebaran virus yang terus meningkat dari waktu ke waktu. Semua aktivitas manusia berubah 180' dengan diberlakukannya PSBB (Pembatasan Sosial 
Berskala Besar) di sejumlah daerah terdampak di Indonesia. Pemerintah menyarankan agar semua orang melakukan semua kegiatannya di rumah dengan istilah "stay at home", sejumlah karyawan dipekerjakan dari rumah (work from home), siswa dan mahasiswa belajar di rumah (study at home), dan sejumlah toko ditutup sementara kecuali toko-toko yang bersifat urgency seperti apotik dan sembako. Pemberlakuan PSBB setidaknya memberikan efek yang signifikan bagi kegiatan masyarakat termasuk dalam usaha dalam pemenuhan kebutuhan hidup. Hal ini menyebabkan perubahan perilaku konsumen dalam berbelaja. Oleh karenanya, tidak sedikit masyarakat yang memutuskan menggunakan e-commerce untuk berbelanja berbagai kebutuhan. Salah satunya melalui Online Marketplace Platform seperti Shopee, Tokopedia, Bukalapak, Lazada dan Blibli. Model bisnis yang ada pada online marketplace saat ini tidak hanya model bisnis bussiness to consumer (B2C), tetapi juga consumer to consumer (C2C). Dimana pihak penjual pada online marketplace tidak disyaratkan untuk memiliki bentuk organisasi bisnis yang legal, tetapi juga perseorangan.

Dirjen Penyelenggaraan Pos dan Informatika (PPI) Kominfo, menyampaikan jumlah transaksi pada onlineshop selama pandemi berlangsung meningkat $400 \%$ dan diprediksi akan terus berlanjut pada era new normal (https://ugm.ac.id, n.d.). Semakin banyaknya transaksi online selama pandemi COVID-19 menimbulkan persaingan ketat bagi pelaku bisnis pada online marketplace di Indonesia. Hal ini membuat tantangan yang harus dihadapi oleh pelaku bisnis dalam merebut dan mempertahankan marketshare yaitu dengan tetap meningkatkan minat konsumen untuk membeli produk-produk pada merchant mereka (purchase intention). Purchase intention dapat diartikan pula sebagai minat konsumen untuk melakukan pembelian produk di masa yang akan datang (Hsu \& Tsou, 2011; Saxena, 2011). Minat seseorang dapat tercermin melalui penilaian terhadap sebuah produk. Kaitannya dengan pemasaran, minat konsumen terhadap suatu produk berpengaruh besar terhadap keputusan pembelian yang akan dilakukan. Purchase intention merupakan derajat kecenderungan atau sejauh mana konsumen memiliki keinginan atau minat terhadap suatu produk serta kemungkinan untuk membelinya (Subagio \& Rachmawati, 2020). Minat seseorang akan muncul dari penilaian suatu produk berdasarkan informasi yang mereka dapatkan. Semakin positif penilaiannya, semakin tinggi pula keinginan dan minatnya terhadap produk tersebut. Purchase intention yang dimiliki oleh konsumen pada produk didasari oleh kepercayaan terhadap produk dan kemampuan untuk membeli produk tersebut. Disisi lain, purchase intention juga dapat terjadi akibat pengaruh orang lain yang mereka percaya. Dalam kaitannya dengan pemasaran, purchase intention menjadi syarat awal sebelum seseorang melalukan keputusan pembelian. Dengan demikian, purchase intention mampu memprediksi perilaku pembelian yang nyata. Subagio dan Rachmawati (2020) menyatakan bahwa indikator yang bisa digunakan untuk mengukur purchase intention pada online marketplace terdiri atas: transactional intention, referential intention, preferential intentention, and explorative intention.

Rahman et al. (2020) menyatakan bahwa promosi price discount merupakan salah satu daya tarik yang sangat diminati oleh konsumen pada Online Marketplace Platform. Strategi price discount merupakan marketing strategy berdasarkan harga yang mana konsumen ditawarkan dengan barang yang sama tetapi dengan harga yang sudah diturunkan. Strategi ini bertujuan agar volume penjualan meningkat (Rohaeni, 2016). Terlebih ketika dihadapkan dengan pandemi COVID-19 konsumen menjadi lebih sensitif terhadap harga. Hal ini disebabkan oleh pendapatan masyarakat yang semakin menurun setelah diterapkannya physical distancing dan PSBB. Masyarakat menilai bahwa kondisi ekonomi nasional secara umum buruk (57,6\% responden) dan sangat buruk (23,4\% responden), sepanjang periode COVID-19 (https://ekonomi.bisnis.com/). Strategi price discount dilakukan dengan 
tujuan untuk menarik minat konsumen dengan menawarkan penghematan dari harga normal. Ketika konsumen melihat harga diskon lebih rendah dibandingkan harga normal, konsumen akan berfikir peluang dalam penghematan biaya yang akan dikeluarkan untuk mendapatkan suatu barang. Beberapa Online Marketplace Platform melakukan promosi harga dengan menggunakan price discount melalui berbagai program diantaranya "Gratis Ongkir", "Cash Back", "Flash Sale", maupun promo-promo lainnya. Program ini secara tidak langsung dapat menarik minat konsumen untuk membeli barang pada Online Marketplace Platform. Hal tersebut sependapat dengan penelitian Agmeka et al. (2019) yang menyatakan bahwa discount price mampu meningkatkan purchase intention konsumen. Agmeka et al. (2019) menyatakan bahwa indikator yang bisa digunakan untuk mengukur price discount pada online marketplace terdiri atas: attact attention, encourage buyer to shop, dan reduce competitors promotion.

Informasi produk dibutuhkan konsumen agar lebih mengenai produk yang akan dibelinya, tujuannya adalah untuk meminimalisir dampak negatif yang didapatkannya setelah membeli produk tersebut. Berbeda dengan toko konvensional yang mengandalkan tatap muka antara penjual dan pembeli, cara mudah untuk mendapatkan informasi pada online marketplace adalah dengan melihat ulasan atau review dan melihat peringkat atau rating pada suatu toko. Online Customer Review (OCR) merupakan fitur pada Online Marketplace Platform yang merupakan perkembangan dari e-WOM (electronic World of Mouth) yang sebelumnya sudah dikenal di media online. OCR berisikan hasil dari pengetahuan dan pengalaman konsumen yang telah membei sebuah produk sebelumnya. Informasi yang dibagikan oleh konsumen dalam OCR dapat berupa ulasan produk, respons penjual, kecepatan pengiriman, dan rating (Díaz \& Espino-Rodríguez, 2018; Kusumasondjaja et al., 2012). Informasi yang terdapat pada OCR dapat memberikan dampak positif dan negatif bagi pelaku bisnis pada Online Marketplace Platform. Konsumen yang puas terhadap pelayanan dan produk yang diberikan oleh merchant cenderung akan memberikan rating yang tinggi pada penilaian merchant dan juga sebalikya. OCR digunakan sebagai salah satu input system reputasi dan kredibilitas penjual yang dapat membantu proses pembentukan kepercayaan konsumen terhadap akun merchant pada lingkungan online marketplace (Tadelis, 2016). Subagio dan Rachmawati (2020) menyatakan bahwa kredibilitas secara implisit dapat membangun image atau citra produk sehingga mampu menurunkan atau meningkatkan nilai dari produk yang dipasarkan.

Informasi konsumen yang terkandung dalam fitur OCR tidak hanya berguna sebagai informasi bagi konsumen potensial, akan tetapi juga dapat berfungsi sebagai rekomendasi konsumen (recommender) (Kusumasondjaja et al., 2012) serta dapat membangun kepercayaan konsumen terhadap merchant. Kepercayaan merupakan factor penting terutama pada bisnis online (Subagio et al., 2018). Hal ini disebabkan tidak adanya interaksi langsung atau tatap muka sehingga resiko yang dirasakan oleh konsumen akan semakin tinggi, seperti resiko penipuan. Dzulqarnain (2019) menyatakan bahwa indikator yang bisa digunakan untuk mengukur OCR pada online marketplace terdiri:: 1) Perceived Usefulness: manfaat yang dirasakan oleh konsumen dengan adanya ulasan pelanggan; 2) Source Credibility: kepercayaan konsumen terhadap kredibilitas sumber dan informasi yang diberikan pada OCR; 3) Argument Quality: mengacu pada kekuatan persuasive argument pada informasi OCR; 4) Valence: mengarah pada sifat positif atau negatif dari pernyataan pada pesan OCR; 5) Volume of Review: mempresentasikan jumlah konsumen yang tertarik dengan pembelian sebelumnya. Hal ini juga berkaitan dengan predikat merchant sebagai star seller atau tidak.

Berdasarkan pemaparan fenomena dan permasalahan yang terjadi selama pandemi COVID-19 penulis tertarik untuk 
meneliti pengaruh price discount terhadap purchase intention dengan dimediasi OCR (Online Customer Review) pada Online Marketplace Platform selama pandemi COVID-19 di Indonesia. Adapun kerangka konseptual penelitian ini adalah sebagai berikut:

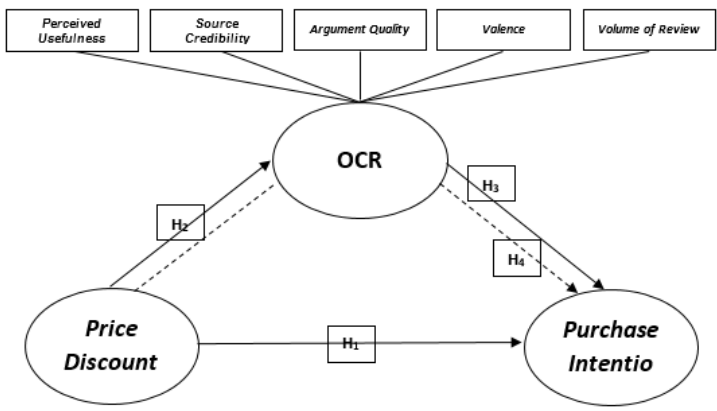

Gambar 1. Kerangka Konseptual

Sumber: Dikembangkan oleh peneliti (2020)

Penelitian yang dilakukan oleh Nusair et al., (2010); Faryabi (2012); dan Rahman et al. (2020) menyatakan bahwa price discount secara signifikan mampu mempengaruhi consumer's purchase intention. Selain itu, price discount yang ditawarkan oleh merchant atau platform online makterplace akan berpengaruh signifikan terhadap persepsi konsumen terhadap online customer review (Albuquerque et al.,2012; Lu et al., 2013, dan Book et al., 2016). Selanjutnya, Zhao et al. (2015), Chua dan Banerjee (2015), Khammash (2008) sepakat bahwa OCR atau umpan balik, penilaian dan rekomendasi dari konsumen yang berpengalaman dalam membeli produk mampu menimbulkan minat beli konsumen potensial.

Berdasarkan gambar diatas dan dukungan dari hasil penelitian sebelumnya, penelitian ini dilakukan untuk menguji apakah price discount $(\mathrm{X})$ berpengaruh pada OCR (Z) dan purchase intention (Y). Selajutnya akan dilakukan pengujian apakah OCR mampu memediasi hubungan antara price discount dengan purchase intention. Maka hipotesa pada penelitian ini sebagai berikut:

$\mathrm{H}_{1}$ : Price discount berpengaruh langsung terhadap purchase intention
$\mathrm{H}_{2}$ : Price discount berpengaruh langsung terhadap OCR (Online Customer Review)

$\mathrm{H}_{3}$ : OCR (Online Customer Review) berpengaruh langsung terhadap purchase intention

$\mathrm{H}_{4}$ : OCR (Online Customer Review) mampu memediasi hubungan price discount terhadap purchase intention

\section{METODE}

Metode yang digunakan pada penelitian ini adalah kuantitatif dengan jenis penelitian eksplanatori (explanatory research) yang berguna untuk menganalisis sejauh mana hubungan antara dua variabel atau lebih, dimana perubahan dalam satu variable tercermin di dalam perubahan satu variable lainnya (Creswell, 2017). Penelitian ini menggunakan metode analisis Structural Equation Model (SEM) dengan pendekatan Variance Based SEM atau lebih dikenal dengan Partial Least Square (PLS). PLS menggunakan metode bootstraping atau penggandaan secara acak, maka asumsi normalitas tidak akan menjadi masalah dalam PLS (Hussein, 2015).

Penelitian dilakukan pada bulan JuniDesember 2020. Penelitian ini dilakukan dengan menyebar kuesioner secara online pada konsumen Online Marketplace Platform (Shopee, Tokopedia, Bukalapak, Lazada dan Blibli) di Indonesia selama pandemi COVID19. Pemilihan kelima online marketplace tersebut dengan pertimbangan Shopee, Tokopedia, Bukalapak, Lazada dan Blibli secara berturut-turut merupakan online marketplace terbesar di Indonesia dengan pengguna lebih dari 17 juta per bulan (https://iprice.co.id, n.d.). Hal ini menggambarkan bahwa banyak konsumen yang memiliki minat positif terhadap online marketplace tersebut. Selain itu, Shopee, Tokopedia, Bukalapak, Lazada dan Blibli memiliki fitur OCR dan juga menerapkan strategi price discount. Dengan demikian peneliti dapat memperoleh gambaran dengan valid terkait dengan pengaruh penerapan strategi OCR dan price discount terdahap purchase intention. 
Seluruh konsumen Online Marketplace Platform (Shopee, Tokopedia, Bukalapak, Lazada dan Blibli) di Indonesia selama pandemi COVID-19 menjadi populasi pada penelitian ini. Teknik non-probability sampling dengan pendekatan purposive sampling dipilih sebab populasi tidak memiliki besaran yang pasti sehingga peluang dari anggota populasi untuk dijadikan sample tidak sama yaitu dengan berdasarkan kriteriakriteria tertentu sesuai dengan tujuan penelitian (Abdillah \& Jogiyanto, 2015). Kriteria yang ditetapkan dalam pengambilan sampel untuk penelitian ini adalah responden yang memiliki kriteria diantaranya memiliki account dan merupakan konsumen pada online marketplace serta pernah melakukan pembelian minimal 1 kali pada Online Marketplace Platform selama pandemi COVID-19.

Hair, Jr (2015) menyatakan bahwa ukuran sampel tergantung pada jumlah indikator yang digunakan pada seluruh variabel laten, sehingga jumlah sampel dapat dihitung dengan mengalikan 5 sampai dengan 10 jumlah indikator. Jumlah sampel yang dibutuhkan dalam penelitian ini sebesar $10 \mathrm{x}$ $12=120$ responden .

Teknik pengumpulan data yang digunakan dalam penelitian ini adalah menyebarkan kuisioner secara online dengan menggunakan Skala Likert (skor 1-5). Sedangkan metode analisis data yang digunakan Structural Equation Model (SEM) dengan pendekatan Variance Based SEM atau lebih dikenal dengan Partial Least Square (PLS).

\section{HASIL DAN PEMBAHASAN}

Kuesioner online penelitian ini telah diisi oleh 120 responden dari berbagai wilayah di Indonesia. Rentang usia responden berkisar 18-25 tahun sebanyak 44,4\%, usia 26-30 tahun sebanyak 37\%, usia 31-35 tahun sebanyak $12,3 \%$ dan sisanya merupakan responden dengan usia lebih dari 35 tahun. Hal ini menunjukkan bahwa pengguna Online Marketplace Platform sebagian besar merupakan masyarakat Generasi Y atau lebih sering disebut dengan generasi milenial dan
Generasi $\mathrm{Z}$ yang lebih mengenal dunia internet dibandingkan dengan generasigenerasi sebelumnya. Selanjutnya, responden didominasi oleh perempuan yaitu sebanyak $76,5 \%$, ini memperlihatkan bahwa di Indonesia wanita lebih cenderung gemar berbelanja online dibandingkan dengan lakilaki. Pendapatan responden sebagian besar berkisar Rp3.000.000-Rp4.000.000 per bulan sebanyak 4,7\%, dan diikuti oleh $27,2 \%$ responden dengan pendapatan di atas Rp4.000.000 per bulan, sehingga dapat disimpulkan bahwa responden didominasi oleh masyarakat kelas menengah keatas (upper-middle income) sesuai dengan klasifikasi pendapatan masyarakat berdasarkan data dari Bank Dunia (https://ekonomi.kompas.com/, 2019).

Sebagian besar $(87,7 \%)$ responden memilih Shopee sebagai Online Marketplace Platform yang paling sering digunakan dalam membeli barang secara online selama pandemi Covid-19. Hal ini sejalan dengan https://iprice.co.id (2019) yang menyatakan bahwa Shopee menduduki peringkat pertama sebagai online marketplace yang paling sering dikunjungi oleh masyarakat di Indonesia.

Hasil analisis outer model memperlihatkan bahwa semua indikator valid dan reliable sebab pada uji validitas konvergen, nilai outer loading pada seluruh item indikator $>0,5$ yang artinya tidak perlu ada item pada kuesioner yang dihilangkan dari model. Begitu pula pada uji validitas diskriminan nilai $\sqrt{\text { AVE }}$ seluruh konstruk lebih besar dari korelasi variable laten. Lebih lanjut pada uji reliabilitas diskriminan, konstruk pada variabel price discount, OCR (Online Customer Review), dan purchase intention menunjukkan nilai composite reliability $>0,70$ nilai cronbach alpha $>0,60$ dari seluruh konstruk, begitu juga dengan nilai AVE seluruh konstruk $>0,50$, sehingga dapat dinyatakan bahwa keseluruhan konstruk telah memenuhi syarat reliabilitas.

Evaluasi inner model mempunyai nilai Goodness of Fit (GoF) sebesar 0,42 secara umum mempunyai sifat prediksi yang medium (GoF large) (Ghozali dan Latan, 
2012), artinya model tersebut mempunyai kemampuan yang baik dalam menjelaskan data empiris. Evaluasi koefisien determinasi (R-Square) menunjukkan bahwa variabel OCR dan purchase intention mampu dijelaskan oleh variabel price discount sebesar $46,3 \%$ dan 66,8\%. Evaluasi model struktural melalui Q-Square didapatkan $82,2 \%$ variabel purchase intention dapat diprediksi oleh variable price discount dan OCR.

Hasil analisis dari hipotesis masingmasing jalur yang ditunjukkan oleh Software smartPLS 3.0 sebagai berikut:

Tabel 2. Hasil Analisis Pengujian Hipotesi Pengaruh Langsung

\begin{tabular}{|c|c|c|c|c|}
\hline $\mathrm{H}$ & Hubungan & $\begin{array}{c}\mathrm{t}- \\
\text { hitung }\end{array}$ & $\begin{array}{c}p- \\
\text { values }\end{array}$ & Keterangan \\
\hline $\mathrm{H}_{1}$ & $\begin{array}{l}\text { Price Discount } \\
\rightarrow \text { Purchase } \\
\text { Intention }\end{array}$ & 1,379 & 0,169 & $\begin{array}{c}\text { Tidak } \\
\text { Signifikan }\end{array}$ \\
\hline $\mathrm{H}_{2}$ & $\begin{array}{l}\text { Price Discount } \\
\rightarrow \text { OCR }\end{array}$ & 7,450 & 0,000 & Signifikan \\
\hline $\mathrm{H}_{3}$ & $\begin{array}{l}\text { OCR } \rightarrow \\
\text { Purchase } \\
\text { Intention }\end{array}$ & 8,612 & 0,000 & Signifikan \\
\hline
\end{tabular}

Sumber: Dikembangkan oleh peneliti, 2020

Hasil pengujian hipotesis pada Tabel 2 menunjukkan $\mathrm{H}_{2}$ dan $\mathrm{H}_{3}$ mempunyai nilai $t$ statistics $>1,96$ serta nilai $p$-values $<0,05$, sehingga dapat dinyatakan signifikan dan dapat disimpulkan bahwa hipotesis diterima. Berbeda dengan $\mathrm{H}_{1}$, nilai $t$-statistics $<1,96$ dan nilai $p$-values $>0,05$, maka hasilnya dapat dikatakan tidak signifikan sehingga dapat disimpulkan bahwa variabel price discount tidak berpengaruh signifikan terhadap purchase intention. Oleh karena itu, hipotesis 1 ditolak.

Tabel 3. Hasil Analisi Pengujian Hipotesis Pengaruh Tidak Langsung

\begin{tabular}{ccccc}
\hline $\mathrm{H}$ & Hubungan & $\begin{array}{c}\mathrm{z}- \\
\text { value }\end{array}$ & $\begin{array}{c}p- \\
\text { values }\end{array}$ & Keterangan \\
\hline $\mathrm{H}_{4}$ & $\begin{array}{l}\text { Price Discount } \\
\rightarrow \text { OCR } \rightarrow\end{array}$ \\
& $\begin{array}{l}\text { Purchase } \\
\text { Intention }\end{array}$ & 5,660 & 0,000 & Signifikan \\
& & & \\
\hline Sumber: Data primer diolah, 2020 & &
\end{tabular}

Tabel 3 menunjukkan bahwa $\mathrm{H}_{4}$ ditolak sebab memiliki nilai $t$-statistics $>1,96$ serta nilai $p$-values $<0,05$, sehingga dapat dinyatakan signifikan. Sehingga dapat disimpulkan bahwa OCR secara signifikan mampu memediasi hubungan antara variabel price discount dan purchase intention.

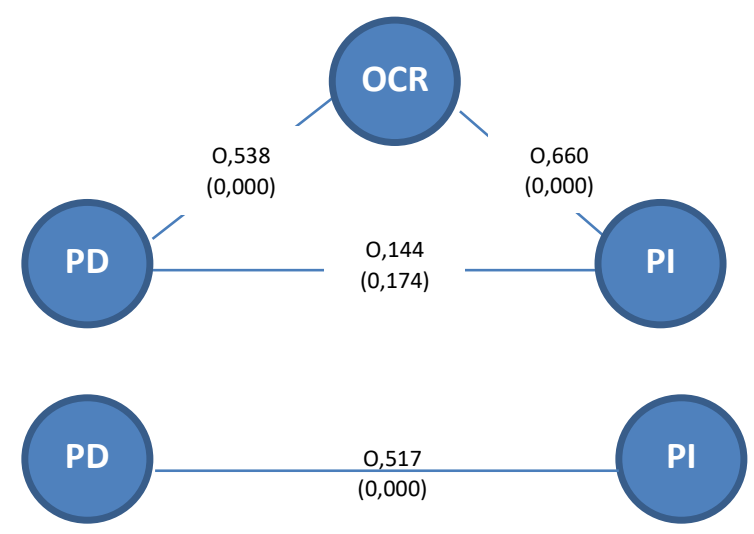

Gambar 2. Model Direct Effect dan Indirect Effect Peran Mediasi OCR

Sumber: Data primer diolah, 2020

Gambar 2 memperlihatkan koefisien direct effect pada price discount terhadap purchase intention (c) adalah 0,517. Koefisien indirect effect (c") dengan variable mediasi OCR (online customer review) berubah menjadi 0,144 serta menjadi tidak signifikan. Sehingga dapat diartikan, OCR mampu memediasi hubungan variable price discount dan purchase intention. Dalam hal ini, variabel OCR bersifat full mediation atau mediasi penuh sebab terjadi perubahan menjadi tidak signifikan.

\section{Pengaruh Price Discount terhadap Purchase Intention.}

Analisis penelitian menunjukkan bahwa price discount tidak berpengaruh signifikan terhadap purchase intention dengan $p$-values sebesar 0,169. Penelitian yang dilakukan oleh Bhatti (2018) serta Amanah dan Harahap (2018) sejalan dengan hasil pada penelitian ini, yang menyatakan bahwa potongan harga pada toko online tidak signifikan dalam meningkatkan minat beli konsumen. Responden pada penelitian ini sebagian besar memiliki pendapatan berkisar Rp3.000.000-Rp4.000.000 per bulan sebanyak 45,7\%, dan diikuti oleh $27,2 \%$ responden dengan pendapatan diatas 4 juta 
rupiah per bulan, sehingga dapat disimpulkan bahwa responden didominasi oleh masyarakat kelas menengah keatas (upper-middle income). Bagi mereka harga tidak terlalu penting dalam pembelian suatu produk di saat pandemi Covid-19 berlangsung asal produk yang dibeli memiliki kualitas dan layanan yang sesuai dengan keinginan mereka. Promosi harga yang terdapat pada Online Marketplace Platform dengan menggunakan price discount melalui berbagai program diantaranya "Gratis Ongkir", "Cash Back", "Flash Sale", maupun promo-promo lainnya secara langsung dapat menarik minat konsumen untuk membeli barang pada Online Marketplace Platform tersebut. Salah satu faktor dominan yang mempengaruhinya yaitu faktor kepercayaan konsumen terhadap produk yang akan dibeli. Berbeda dengan toko konvensional, pada Online Marketplace Platform konsumen tidak dapat melihat produk dengan nyata. Sehingga tidak mudah bagi konsumen potensial untuk menilai apakah price discount yang ditawarkan akan mempengaruhi kualitas dari produk yang akan didapatkan. Kim et al. (2012) juga menyatakan bahwa kepercayaan pada toko online lebih kuat berpengaruh dibandingkan dengan harga. Namun harga akan berpengaruh kuat bagi konsumen reguler yang sudah melakukan pembelian berulang pada produk dan toko online yang sama. Berbeda dengan konsumen potensial yang masih merasakan ketidakpastian dari produk yang akan dibeli. Konsumen potensial akan cenderung melihat deskripsi produk, foto produk, rating, dan ulasan konsumen yang telah melakukan pembelian pada OCR (Online Customer Review) daripada melihat potongan harga yang ditawarkan dengan tujuan untuk mengurangi risiko adanya ketidaksesuaian antara harapan dengan produk yang diterima.

\section{Pengaruh Price Discount terhadap OCR} (Online Customer Review).

Price discount yang ditawarkan oleh merchant atau platform online makterplace akan berpengaruh signifikan terhadap persepsi konsumen terhadap online customer review. Hal ini sejalan dengan penelitian yang dilakukan oleh Albuquerque et al. (2012), Lu et al. (2013), dan Book et al. (2016). Price discount bertujuan untuk menarik minat konsumen dengan menawarkan penghematan dari harga normal. Ketika konsumen melihat harga diskon lebih rendah dibandingkan harga normal, mereka akan berfikir peluang dalam penghematan biaya yang akan dikeluarkan untuk mendapatkan suatu barang. Di masa pandemi Covid-19 berlangsung banyak Online Marketplace Platform berlombalomba dalam menawarakan strategi promo berupa diskon kepada konsumen. Konsumen yang mendapatkan tawaran tersebut cenderung akan memastikan apakah promo yang ditawarkan akan mempengaruhi kualitas pelayanan dan produk yang akan diterima. Oleh karenanya, konsumen akan mencari informasi tersebut secara lebih detail melalui ulasan-ulasan yang telah dibuat oleh konsumen lain yang sudah membeli produk sebelumnya. Ulasan pada OCR dianggap lebih meyakinkan dibanding dengan deskripsi yang tercantum pada halaman produk. Informasi tersebut meliputi dimensi nyata dari produk berupa gambar maupun video, kualitas packaging barang, kecepatan dalam pengiriman, kualitas barang disbanding dengan harga yang ditawarkan, serta layanan yang diberikan. Informasi yang didapatkan konsumen potensial dapat meningkatkan kepercayaan konsumen terhadap produk yang akan dibeli.

\section{Pengaruh OCR (Online Customer Review) terhadap Purchase Intention.}

Analisis hasil penelitian

memperlihatkan bahwa variable OCR (online customer review) memiliki hubungan yang signifikan pada purchase intention. Sehingga dapat diartikan bahwa ulasan atau komentar yang diberikan oleh konsumen yang telah membeli produk pada Online Marketplace Platform mampu meningkatkan minat beli konsumen yang membacanya. Hal ini sejalan dengan penelitian yang dilakukan oleh Zhao et al. (2015), Chua dan Banerjee (2015), Khammash (2008) yang sepakat bahwa OCR atau umpan balik, penilaian dan rekomendasi 
dari konsumen yang berpengalaman dalam membeli produk mampu menimbulkan minat beli konsumen potensial.

Perilaku belanja secara online memiliki perbedaan dengan berbelanja langsung di toko-toko konvensional. Konsumen tidak dapat melihat produk secara nyata, sehingga kesulitan dalam mengevaluasi produk yang akan dibeli. Oleh karenanya. OCR secara umum berguna bagi konsumen potensial dalam mengevaluasi informasi-informasi produk yang telah diulas oleh konsumen yang sudah melakukan pembelian sebelumnya. OCR merupakan bagian dari UCG (User Generated Content) dimana pengguna dapat membuat konten dan mempublikasikan dalam sebuah system. Hal ini menjadi sangat penting di era digitalisasi dimana review konsumen bersifat independen dan memiliki kekuatan dalam proses pemasaran produk. Konsumen secara bebas dapat memberikan ulasan positif maupun negatif pada sebuah produk yang sudah dibeli sesuai dengan pengalamannya. Ulasan tersebut menjadi salah satu sumber informasi yang bernilai bagi konsumen potensial untuk mengevaluasi informasi produk sebelum melakukan pembelian, sebab informasi yang disajikan oleh konsumen dinilai tidak memihak dan lebih dipercaya. Sehingga OCR dapat mempengaruhi minat beli (purchase intention) konsumen potensial dan membantu proses keputusan pembelian (Chua \& Banerjee, 2015).

Perceived usefulness merupakan indikator OCR dengan rata-rata skor tertinggi yaitu 4,68 pada hasil kuesioner. Hal ini mengindikasikan bahwa konsumen merasakan manfaat dari OCR pada Online Marketplace Platform. Ulasan pada OCR mempermudah konsumen dalam memperoleh informasi nyata dari produk-produk yang ditawarkan oleh toko online atau merchant. OCR dapat mengurangi keraguan konsumen potensial dalam membeli barang secara online seperti, apakah barang yang ditawarkan merchant tersebut sesuai dengan gambar atau tidak, apakah kualitas produk layak atau tidak, selain itu apakah harga yang ditetapkan sebanding dengan kualitas produk yang dijual. Dengan kata lain, OCR juga membantu konsumen potensial dalam mengurangi risiko pembelian suatu produk. Jika ulasan dinilai kurang positif, konsumen dapat melakukan antisipasi sebelum melakukan pembelian dan jika ulasan yang diberikan rata-rata positif, maka minat beli konsumen terhadap suatu produk akan meningkat.

\section{Peran OCR (Online Customer Review) terhadap Hubungan Price Discount dan Purchase Intention.}

Hasil analisis startistik

menggambarkan bahwa variabel OCR memediasi penuh (full mediation) hubungan antara price discount dengan purchase intention. Artinya keberadaan OCR dirasa sangat bermanfaat untuk meyakinkan konsumen dan meningkatkan minat beli konsumen ketika Online Marketplace Platform atau merchant menawarkan potongan harga dari sebuah produk.

Pada penelitian ini, Shopee menduduki peringkat pertama sebagai Online Marketplace Platform yang paling digemari oleh responden pada saat pandemi Covid-19 berlangsung. Data tersebut sejalan dengan hasil riset yang dilakukan oleh https://iprice.co.id (2019) yang menyatakan bahwa Shopee sangat diminati oleh masyarakat Indonesia sebagai platform untuk berbelanja untuk memenuhi kebutuhan secara online. Minat konsumen pada sebuah Online Marketplace Platform dipengaruhi oleh beberapa faktor. Terdapat 2 faktor dominan yang disampaikan responden pada penelitian ini, diantaranya memberikan kemudahan dalam berbelanja dan banyaknya promosi price discount yang ditawarkan. Pada era pandemi, sebagian masyarakat lebih sensitif terhadap harga. Stimulus marketing berupa price discount terlihat lebih menarik oleh sebagian orang, namun potongan harga ini tidak selalu memberikan pandangan positif akan tetapi juga dapat memberikan image negative pada sebuah produk (Rahman et al., 2020). Masyarakat dengan tingkat pendapatan menengah keatas cenderung tidak terpengaruh terhadap tawaran potongan harga, mereka akan cenderung menilai 
apakah barang yang akan dibeli sesuai dengan apa yang diinginkannya. Sebelum melakukan keputusan pembelian, konsumen pada Online Marketplace Platform hanya mendapatkan informasi yang terbatas terkait dengan produk. Pada saat konsumen mengalami ketidakpastian dalam berbelanja online, konsumen akan membutuhkan banyak informasi yang lebih detail dan spesifik. Oleh karenanya konsumen potensial akan terdorong untuk mencari informasi yang lebih lengkap melalui review yang diberikan oleh konsumen yang telah berpengalaman dalam membeli dan mengkonsumsi produk tersebut, tidak peduli apakah ulasan berisikan pesan yang negatif maupun positif. Ulasan pada OCR akan membentuk sebuah persepsi dan bahan pertimbangan serta rekomendasi bagi konsumen terhadap produk yang akan dia beli. Dengan kata lain, Online Customer Review (OCR) dapat membantu konsumen dalam mengurangi risiko yang akan diterima apabila membeli produk tersebut. Oleh karenanya, sebuah strategi price discount akan lebih efektif dalam meningkatkan minat beli konsumen (purchase intention) apabila disertai dengan ulasan-ulasan positif pada OCR oleh konsumen yang telah membeli dan mengkonsumsi produk tersebut.

\section{Kesimpulan}

Pandemi Covid-19 memberikan dampak yang signifikan bagi kegiatan masyarakat termasuk dalam perilaku berbelanja. Banyak masyarakat yang akhirnya menggunakan e-commerce untuk berbelanja berbagai kebutuhan. Shopee merupakan satu dari beberapa online marketplace yang paling digemari oleh masyarakat Indonesia untuk berbelanja secara online. Strategi promosi price discount yang ditawarkan tidak serta merta dapat menarik minat semua konsumen untuk membeli produk pada Online Marketplace Platform meskipun keadaan perekonomian secara umum menurun. Responden penelitian ini didominasi oleh masyarakat upper-middle income yang mana tidak terlalu sensitive terhadap promosi potongan harga. Oleh karenanya, price discount tidak berpengaruh secara signifikan terhadap purchase intention. Akan tetapi strategi price discount secara signifikan dapat mempengaruhi konsumen dalam membaca OCR (Online Customer Review). Ketika mendapati potongan harga, konsumen cenderung akan menilai apakah barang yang akan dibeli sesuai dengan apa yang diinginkannya atau tidak. Informasi tersebut akan didapatkan secara lebih detail dan konkrit melalui OCR yang dibuat oleh konsumen yang telah berpengalaman dalam membeli dan mengkonsumsi produk. Ulasan yang terdapat pada OCR akan membentuk sebuah persepsi, bahan pertimbangan, dan rekomendasi bagi konsumen terhadap produk yang akan dia beli. Dengan kata lain, OCR akan membantu konsumen dalam meningkatkan keyakinan atau kepercayaan serta minat beli (purchase intention) konsumen terhadap suatu produk. Hal ini menjadikan OCR berpengaruh signifikan terhadap minat beli konsumen serta mampu memediasi hubungan antara price discount dan purchase intention.

Berdasarkan kesimpulan beberapa temuan penting dalam penelitian, maka peneliti menyarankan agar penelitian selanjutnya bisa mempertimbangkan untuk memperbanyak ukuran sampel penelitian, objek penelitian tidak hanya pada konsumen akhir akan tetapi juga pada merchant sebagai konsumen internal pada online marketplace platform yang rentan untuk berpindah atau switching pada platform lainnya, dan penelitian selanjutnya dapat memperluas dan mengintegrasikan model penelitian dengan memasukkan faktor-faktor yang mungkin dapat mempengaruhi purchase intention.

\section{DAFTAR PUSTAKA}

Abdillah, W., \& Jogiyanto, H. (2015). Partial Least Square (PLS) Alternatif Structural Equation Modeling (SEM) dalam Penelitian Bisnis. Yogyakarta: Andi.

Agmeka, F., Wathoni, R. N., \& Santoso, A. S. (2019). The influence of discount framing towards brand reputation and brand image on purchase intention and actual behaviour in e-commerce. Procedia Computer Science, 161, 851- 
858.

https://doi.org/10.1016/j.procs.2019.11. 192

Albuquerque, P., Pavlidis, P., Chatow, U., Chen, K. Y., \& Jamal, Z. (2012). Evaluating promotional activities in an online two-sided market of usergenerated content. Marketing Science. 31(3), 406-432 https://doi.org/10.1287/mksc.1110.0685 Amanah, D., \& Harahap, D. A. (2018). Examining the effect of product assortment and price discount toward online purchase decision of university student in Indonesia. Jurnal Manajemen Dan Kewirausahaan, 20(2), 99-104. https://doi.org/10.9744/jmk.20.2.99-104

Bhatti, A. (2018). Sales Promotion and Price Discount Effect on Consumer Purchase Intention with the Moderating Role of Social Media in Pakistan. International Journal of Business Management, 3(4), 50-58.

Book, L. A., Tanford, S., \& Chen, Y. S. (2016). Understanding the impact of negative and positive traveler reviews: social influence and price anchoring effects. Journal of Travel Research. 55(8), 993-1007 https://doi.org/10.1177/0047287515606 810

Chua, A. Y. K., \& Banerjee, S. (2015). Understanding review helpfulness as a function of reviewer reputation, review rating, and review depth. In Journal of the Association for Information Science and Technology. 66(2), 354-362 https://doi.org/10.1002/asi.23180

Creswell, J. W. (2017). John W. Creswell, Research design: qualitative, quantitative, and mixed methods approaches. Journal of Social and Administrative Sciences. 4(2), 205-207

Díaz, M. R., \& Espino-Rodríguez, T. F. (2018). Determining the reliability and validity of online reputation databases for lodging: Booking.com, tripadvisor, and holidaycheck. Journal of Vacation Marketing. 24(3), 261-274 https://doi.org/10.1177/1356766717706
103

Dzulqarnain, I. (2019). Pengaruh Fitur Online Customer Review terhadap Keputusan Pembelian Produk Pada Marketplace Shopee. Skripsi. Universitas Jember. Repostory Universitas Jember. http://repostrory.unej.ac.id

Faryabi, M. (2012). The effect of price discounts and store image on consumer's purchase intention in online shopping context case study: nokia and htc. journal of Business Studies Quarterly, 4(1), 197-205.

Hair, Jr, J. F. (2015). Essentials of Business Research Methods. New York: Taylor \& Francis Group. https://doi.org/10.4324/9781315704562

Hsu, H. Y., \& Tsou, H. T. (2011). Understanding customer experiences in online blog environments. International Journal of Information Management. 31(6), 510-523 https://doi.org/10.1016/j.ijinfomgt.2011. 05.003

Https://ekonomi.bisnis.com/. (n.d.). Pandemi Covid-19 Bikin Ekonomi Buruk Ekonomi Bisnis.com. https://ekonomi.bisnis.com/read/202006 08/9/1249847/pandemi-covid-19-bikinekonomi-buruk-istana-kita-masih-bisabertahan

https://ekonomi.kompas.com/. (2019). Indonesia Kini Jadi Negara Berpendapatan Menengah ke Atas.

https://iprice.co.id. (n.d.). Top 50 ECommerce Sites \& Apps in Indonesia 2019.

https://iprice.co.id/insights/mapofecom merce/en/

https://ugm.ac.id. (n.d.). Transaksi Penjualan Online Naik 400 Persen di Masa Pandemi Covid-19| Universitas Gadjah Mada. https://ugm.ac.id/id/berita/19452transaksi-penjualan-online-naik-400persen-di-masa-pandemi-covid-19

Hussein, A. S. (2015). Penelitian Bisnis dan Manajemen Menggunakan Partial Least Squares dengan SmartPLS 3.0. Universitas Brawijaya. 
https://doi.org/10.1023/A:10232025193 95

Khammash, M. (2008). Electronic word-ofmouth: antecedents of reading customer reviews in on-line opinion platforms: A quantitative study from the uk market. IADIS International Conference WWW/Internet 2008.

Kim, H., Xu, Y., \& Gupta, S. (2012). Which is more important in internet shopping, perceived price or trust?. Electronic Commerce Research and Applications. 11(3), 241-252

Kusumasondjaja, S., Shanka, T., \& Marchegiani, C. (2012). Credibility of online reviews and initial trust: The roles of reviewer's identity and review valence. Journal of Vacation Marketing. 18(3),185-195.

https://doi.org/10.1177/1356766712449 365

Lu, X., Ba, S., Huang, L., \& Feng, Y. (2013). Promotional marketing or word-ofmouth? Evidence from online restaurant reviews. Information Systems Research. 24(3), 596-612 https://doi.org/10.1287/isre.1120.0454

Nusair, K., Yoon, H. J., Naipaul, S., \& Parsa, H. G. (2010). Effect of price discount frames and levels on consumers' perceptions in low-end service industries. International Journal of Contemporary Hospitality Management. 22(6), 814-835. https://doi.org/10.1108/0959611101106 3106

Rahman, S. H., Rohaeni, H., Wijaya, S., \& Dewi, K. (2020). Pengaruh Price Discount dan Bonus Pack Terhadap Purchase Intention. Jurnal Sain Manajemen, 2(1), 24-36.

Rohaeni, H. (2016). Peranan Promosi melalui Personal Selling terhadap Volume Penjualan. Ecodemica. 4(2), 223-231

Saxena, A. (2011). Blogs and their impact on purchase intention: a structural equation modelling approach. Paradigm. 15(1-2), 102-110. https://doi.org/10.1177/0971890720110 114
Subagio, D. P. W., Mugiono, M., \& Hadiwidjojo, D. (2018). Pengaruh Perceived Ease of Use terhadap Repurchase Usefulness dan Trust sebagai Variabel Mediasi. Jurnal Manajemen Dan Kewirausahaan. 6(1), 35-44.

Gio, D. P. W., \& Rachmawati, D. L. (2020). Pengaruh Endorser terhadap Purchase Intention dengan Perceived Value dan Perceived Usefulness sebagai Variabel Mediasi ( Studi Pada Viewer Food Vlogger of YouTube Channel ). 8(1), 111.

Tadelis, S. (2016). Reputation and feedback systems in online platform markets. Annual Review of Economics. 8(1, 321340.

O. (2020). Rolling updates on coronavirus disease (COVID-19). Events as They Happen.

Zhao, X. (Roy), Wang, L., Guo, X., \& Law, R. (2015). The influence of online reviews to online hotel booking intentions. International Journal of Contemporary Hospitality Management. 7(5), 3189-3198. https://doi.org/10.1108/IJCHM-122013-0542 